\title{
OXYGEN CONSUMPTION IN THE PROSOBRANCH SNAIL VIVIPARUS CONTECTOIDES (MOLLUSCA: GASTROPODA)-II. EFFECTS OF TEMPERATURE AND $\mathrm{pH}^{*}$
}

\author{
Mary Jill Buckingham and David E. Freed \\ Department of Biology, University of Michigan-Flint, Flint, MI 48503, U.S.A.
}

(Received 14 March 1975)

\begin{abstract}
Metabolic rate (oxygen consumption) of Viviparus contectoides is directly dependent on temperature.

2. Males have a rectilinear relationship between weight-adjusted oxygen consumption and temperature. Females have a curvilinear relationship.

3. There was a significant sexual difference in the relationship of weight-adjusted oxygen consumption and temperature, with the mean value for males being higher than for females at 22 and $27^{\circ} \mathrm{C}$.

4. $Q_{10}$ values for males decreased with increasing temperature, and for females they increased with increasing temperature.

5. Metabolic rate $\left(\dot{\mathrm{V}}_{\mathrm{O}_{2}}\right)$ of $V$. contectoides is dependent on $\mathrm{pH}$, with two $\mathrm{pH}$ optima at $\mathrm{pHs} 7 \cdot 1$ and 8.9 with an intervening trough.
\end{abstract}

\section{INTRODUCTION}

WATER temperature is one of the more important factors affecting oxygen consumption and, therefore, general energetics in aquatic ectotherms. The relationship of ambient temperature to metabolic rate has been investigated in many aquatic invertebrates (Barnes \& Barnes, 1969; Newell, 1969; Newell, 1973; Newell \& Bayne, 1973). Several studies have dealt with molluscs (Lewis, 1971; Newell \& Roy, 1973) including some on snails (Berg \& Ockelmann, 1959; Akerlund, 1969; Haeser, 1970; Mason, 1971; Huebner, 1973).

Another factor which may affect oxygen consumption is $\mathrm{pH}$. We found no studies concerning this relationship in snails; however, Jewell \& Brown (1922) and Jewell (1929) showed that the distribution of snails relates to the $\mathrm{pH}$ of their environment.

This study reports the effects of acute changes in water temperature and $\mathrm{pH}$ on oxygen consumption in Viviparus contectoides (W. G. Binney) and continues a group of articles which report on the relationships of environmental parameters to the energy budgets or metabolism in this species.

\section{MATERIALS AND METHODS}

Basic animal care and procedural techniques have been described in the first paper of this series (Fitch, 1975). Snails of both sexes were acclimated to $22+1^{\circ} \mathrm{C}$ for a minimum of 10 days prior to testing. Tests were conducted between 8 and 12 p.m., the time of minimal metabolic activity in the population studied (Fitch, 1975). Oxygen consumption of individual snails was performed utilizing the Winkler technique (Hoar \& Hickman. 1967) during a $2 \mathrm{hr}$ exposure to the chosen temperature. Eight individuals of each sex were transferred from the holding tank into testing

* Reprint requests should be addressed to Eugene H. Studier, Department of Biology. University of MichiganFlint, Flint, MI 48503, U.S.A. vessels at temperatures 5 or $10^{\circ} \mathrm{C}$ above or below the holding temperature, resulting in tests being conducted at 12 17, 22. 27. or $32^{\circ} \mathrm{C}$. Each snail was tested at only one temperature.

Snails of both sexes were acclimated at a $\mathrm{pH}$ of 8.1 and a temperature of $22 \pm 1^{\circ} \mathrm{C}$ again for a minimum of 10 days prior to testing. Tests were performed as above for a $2 \mathrm{hr}$ exposure to the chosen $\mathrm{pH}$. To minimize increase of osmotic pressure. the $\mathrm{pH}$ of the water was adjusted using hydrochloric acid and sodium hydroxide. Measurements were made at $\mathrm{pH}$ values of $6 \cdot 1,7 \cdot 1.8 \cdot 1.8 \cdot 5,9 \cdot 1$ and 10-1. Each snail was tested at only one $\mathrm{pH}$.

\section{RESULTS}

Table 1 shows the linear and curvilinear relationship between oxygen consumption $\left(\mathrm{cm}^{3} / \mathrm{hr}, \dot{\mathrm{V}}_{\mathrm{O}_{2}}\right.$, and $\mathrm{cm}^{3} / \mathrm{hr}$ per $\mathrm{g}^{\mathrm{b}}$ ) and ambient temperature in males and females. In a previous study (Fitch, 1975), logarithmic comparisons of oxygen consumption and weight were made to determine respiration coefficients $(b)$ for males and females. The value for males was 0.6825 and for females 0.3463 .

The relationship between weight adjusted oxygen consumption and ambient temperature was analyzed with polynomial regression (Table 1, Fig. 1). For males, data are best described by a straight line; however, for females, a curvilinear (second order polynomial) relationship is best. There were no significant differences in weight corrected oxygen consumption between males and females at the minimum $(12$ \& $\left.17^{\circ} \mathrm{C}\right)$ and maximum $\left(32^{\circ} \mathrm{C}\right)$ test temperatures. At the intermediate temperatures $\left(22\right.$ and $\left.27^{\circ} \mathrm{C}\right)$ differences were significant, with the mean value for males being higher than for females $(t=3.2504 ; d . f .=14$; $p=0.0058$, and $t=4.4783 ; d . f .=14 ; p=0.0005$; respectively).

$Q_{10}$ values were calculated for males and females from Fig. 1. These results are shown in Table 2. Over, all, the $Q_{10}$ values were higher for females than for 
Table 1. Terms of the best regression equation: $Y=a+b t$ and $Y=\mathrm{a}+\mathrm{bt}+\mathrm{ct}^{2}$ describing the relationship between temperature $(t)$ and $Y=\mathrm{cm}^{3} / \mathrm{hr}, Y=\dot{\mathrm{V}}_{\mathrm{O}_{2}}$; and $Y=\mathrm{cm}^{3} / \mathrm{hr}$ per $\mathrm{g}^{0.346}$ or $\mathrm{cm}^{3} / \mathrm{hr}$ per $\mathrm{g}^{0.6825}$ ). $N=40$ for each sex. Numbers in parentheses are standard errors

\begin{tabular}{|c|c|c|c|c|}
\hline $\begin{array}{l}\text { Dependernt } \\
\text { vertable }\end{array}$ & $\operatorname{sen}$ & Equation & $\begin{array}{l}\text { S1gn. of } \\
\text { reprivelon }\end{array}$ & $\underline{x}^{2}$ \\
\hline \multirow[t]{2}{*}{ cc/hr } & $\mathbf{x}$ & $-0.0171( \pm 0.0176)+0.0030( \pm 0.008) \mathrm{c}$ & 0.0003 & 0.2928 \\
\hline & $\mathbf{F}$ & $\begin{array}{l}0.1920( \pm 0.0683) \\
0.0006( \pm 0.0002) t^{-0.0203}( \pm 0.0067) t+\end{array}$ & 0.0001 & 0.6422 \\
\hline \multirow[t]{2}{*}{$8_{02}$} & $\mathbf{H}$ & $-0.0577( \pm 0.0237)+0.0053( \pm 0.0010) E$ & 0.0001 & 0.4103 \\
\hline & $\mathbf{7}$ & $\begin{array}{l}0.2210( \pm 0.1678) \\
0.0007( \pm 0.0004) t^{-0.0253}( \pm 0.0164) t+\end{array}$ & 0.0014 & 0.2993 \\
\hline $\mathrm{cc} / \mathrm{hx} / \mathrm{g}^{6825}$ & $\mathbf{M}$ & $-0.4380( \pm 0.0211)+0.0045( \pm 0.0009) t$ & 0.0001 & 0.3886 \\
\hline $\mathrm{cc} / \mathrm{hr} / \mathrm{b}^{3463}$ & $\boldsymbol{\nabla}$ & $\begin{array}{l}0.1438( \pm 0.0550){ }^{-0.0153}( \pm 0.0054) t+ \\
0.0005( \pm 0.0001) t^{2}\end{array}$ & 0.0001 & 0.6621 \\
\hline
\end{tabular}

males. As the temperature increased. values increased for females and decreased for males.

Table 3 shows experimental mean values and S.E. of the means for males and females at each $\mathrm{pH}$. The regression equation is: $Y=-23.5689( \pm 7.8348)+$ $11.7874( \pm 3.9978) x-2.1942 \quad( \pm 0.7566) x^{2}+0.1808$ $( \pm 0.630) x^{3}-0.0056 \quad( \pm 0.0019) x^{4} ; \quad r^{2}=0.5032$ $\bar{N}=107$, where $Y=$ oxygen consumption, $x=\mathrm{pH}$, and numbers in parenthesis are standard errors. There are two peaks at $\mathrm{pH} \simeq 7.1$ and $\mathrm{pH} \simeq 8.9$ and an intervening trough at $\mathrm{pH} \simeq 8.1$ (see Fig. 2).

There were no significant differences in oxygen consumption between males and females that could not be explained by weight differences. The only exception occurred at pH $8 \cdot 1$, where oxygen consumption of males was significantly greater than that of females $(t=2.4599 ; d f .=14 ; p=0.0275)$.

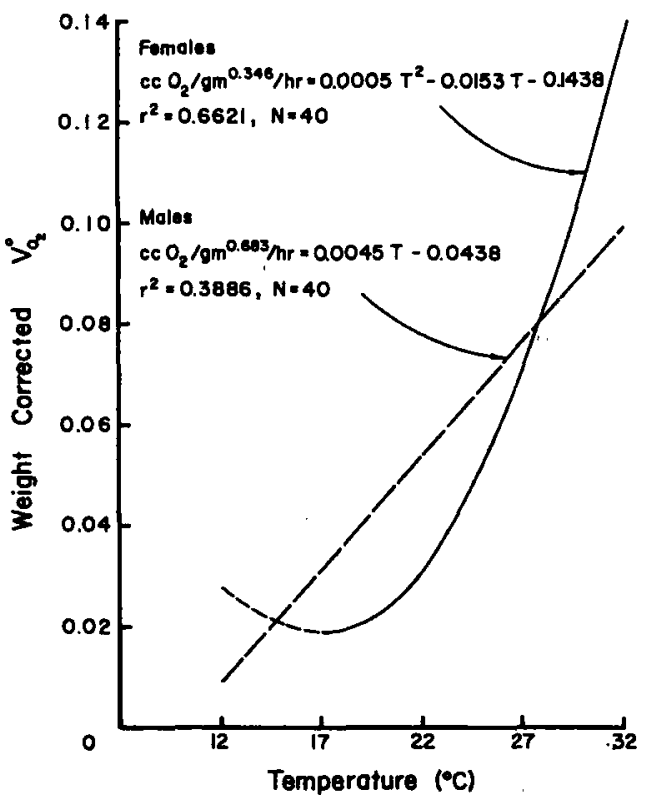

Fig. 1. Weight corrected oxygen consumption $\left(\mathrm{cm}^{3} / \mathrm{g}^{b}\right.$ per $\mathrm{hr})$ in relation to ambient water temperature in $V$. contectoides.

\section{DISCUSSION}

The rate of oxygen consumption is directly related to ambient temperature. Viviparus contectoides follows the expected relationship of increasing oxygen consumption with increasing ambient temperature as seen in other studies (Berg \& Ockelmann, 1959; Davies, 1966; Daniels \& Armitage, 1968; Barnes \& Barnes, 1969; Huebner, 1973; Newell, 1973; Newell \& Bayne, 1973). In a study of Strophocheilus ohlongus musculus, weight specific oxygen consumption (wet wt) was $24.9 \mu \mathrm{l} \mathrm{O} / \mathrm{g}$ per hr at $10^{\circ} \mathrm{C}, 40.9 \mu \mathrm{l} \mathrm{O} \mathrm{O}_{2} / \mathrm{g}$ per hr at $20^{\circ} \mathrm{C}$, and $72.5 \mu \mathrm{l} \mathrm{O}_{2} / \mathrm{g}$ per hr at $30^{\circ} \mathrm{C}$ (Haeser, 1970). The oxygen consumption for Pomatias elegans has been reported to be $23.2711 \mu \mathrm{l} \mathrm{O} / \mathrm{hr}$ at $10^{\circ} \mathrm{C}$ and $29.0553 \mu \mathrm{l} \mathrm{O} / \mathrm{hr}$ at $15^{\circ} \mathrm{C}$ and for Helicella virgata to be $21.6171 \mu \mathrm{l} \mathrm{O} / \mathrm{hr}$ at $10^{\circ} \mathrm{C}$ and $38.4353 \mu \mathrm{l}$

Table 2. $Q_{10}$ value for oxygen consumption in $V$. contectoides

$\begin{array}{lr}- & \\ {\mathrm{C}} } & \frac{\text { MLLES }}{2.53} \\ 17-277^{\circ} \mathrm{C} & 1.91 \\ 22-32^{\circ} \mathrm{C} & 1.61 \\ & \frac{\text { TRHALES }}{3.96} \\ 17-270^{\circ} \mathrm{C} & 4.28 \\ 22-32^{\circ} \mathrm{C} & 4.28\end{array}$

Table 3. Oxygen consumption $\left(\dot{\mathrm{V}}_{\mathrm{O}_{1}}\right)$ for male and female $V$. contectoides at each $\mathrm{pH}$ showing mean oxygen consumption $(\bar{x})$ and standard error of the mean (S.E. $\bar{x})$. Sample size equals eight (8) except as indicated

\begin{tabular}{|c|c|c|c|c|}
\hline & \multicolumn{2}{|c|}{ Males } & \multicolumn{2}{|c|}{ Feanles } \\
\hline 매 & $x$ & $\mathrm{SR}_{\mathrm{K}}$ & $x$ & $\underline{\mathrm{sg}}$ \\
\hline$\$ 6.1$ & 0.0138 & 0.0055 & 0.0218 & 0.0039 \\
\hline 7.2 & 0.0820 & 0.0052 & 0.0637 & 0.0075 \\
\hline 7.5 & 0.0551 & 0.0080 & 0.0491 & 0.0034 \\
\hline 8.1 & 0.0610 & 0.0052 & 0.0416 & 0.0059 \\
\hline 9.1 & 0.0555 & 0.0058 & 0.0413 & 0.0042 \\
\hline 10.1 & 0.0154 & 0.0035 & 0.0132 & 0.0030 \\
\hline
\end{tabular}


$\mathrm{O}_{2} / \mathrm{hr}$ at $15^{\circ} \mathrm{C}$ (Mason, 1971). In V. contectoides, oxygen consumption extends over a much wider range of values for the same temperature ranges. averaging

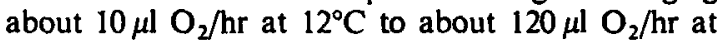
$32^{\circ} \mathrm{C}$.

Metabolic rate is dependent on levels of activity in many species (Rising \& Armitage, 1969; Newell \& Pye, 1971; Newell, 1973; Newell \& Bayne, 1973; Newell \& Roy, 1973) as well as $V$. contectoides (Fitch. 1975). We have attempted to decrease this factor by performing the tests during the time period of minimal metabolic activity. When examining these data, it should be noted that seasonal changes may also affect the oxygen consumption of the snails (Berg et al., 1957; Newell \& Roy, 1973).

It has been shown that the relationship for males is linear and for females is curvilinear. Bartholomew (1972) states that the rate of oxygen consumption follows van't Hoff's rule, which states that oxygen consumption of poikilotherms increases exponentially with increasing temperature. Results of several studies follow this theoretical relationship (Newell, 1966; Haeser, 1970; Roff, 1973), as did females in our study. However, males were unusual in that they showed a linear increase with increasing temperature. Chemical reactions of the body are temperature dependent (Pye \& Newell, 1973). Our study indicates that the temperature dependence of the reaction rates is different between males and females.

In the intermediate temperature ranges $\left(22-27^{\circ} \mathrm{C}\right)$ oxygen consumption was significantly higher for males than for females. It is energetically more advantageous to have a lower metabolic rate, thus females are energetically more efficient at these temperatures. These temperatures represent the summer range, during which time this species reproduces. This species is viviparous, therefore. metabolic demands on the female would be greater during periods of reproduction. On the basis of the linear relationship in males. we might predict that they may be able to occupy a broader temperature range. Conversely. the curvilinear relationship of females may indicate that their range may be more limited by environmental temperature.

$Q_{10}$ values for a linear relationship decrease with increasing temperature, and for a curvilinear relationship they will increase. In the studies of Balamus halanus. Balanus balanoides (Barnes \& Barnes 1969), and three limpet groups (Davies. 1966), there was a decrease of $Q_{10}$ with rising temperature, with the decrease tending to lessen as the temperature rose. This trend was observed for males in our study. The $Q_{10}$ values for females rose with increasing temperature as expected due to the curvilinear temperature relationship. The $Q_{10}$ value for Patella vulgata for $15-25^{\circ} \mathrm{C}$ was 1.68 and for $25-35^{\circ} \mathrm{C}$ was 1.48 (Davies. 1966). The values for $B$. halanoides for $15-25^{\circ} \mathrm{C}$ was 1.13 and for $B$. halanus at $15-25^{\circ} \mathrm{C}$ it was 1.70 (Barnes \& Barnes, 1969). $Q_{10}$ values for both sexes of $V$. contectoides were higher than most published values, indicating that ambient temperature affects oxygen consumption more profoundly in this species.

The rate of oxygen consumption is related to $\mathrm{pH}$ due to increasing and decreasing levels of metabolic activity at different $\mathrm{pH}$ values (see Fig. 2). This population lives at the trough $\mathrm{pH}(8 \cdot 1)$ which is energeti-

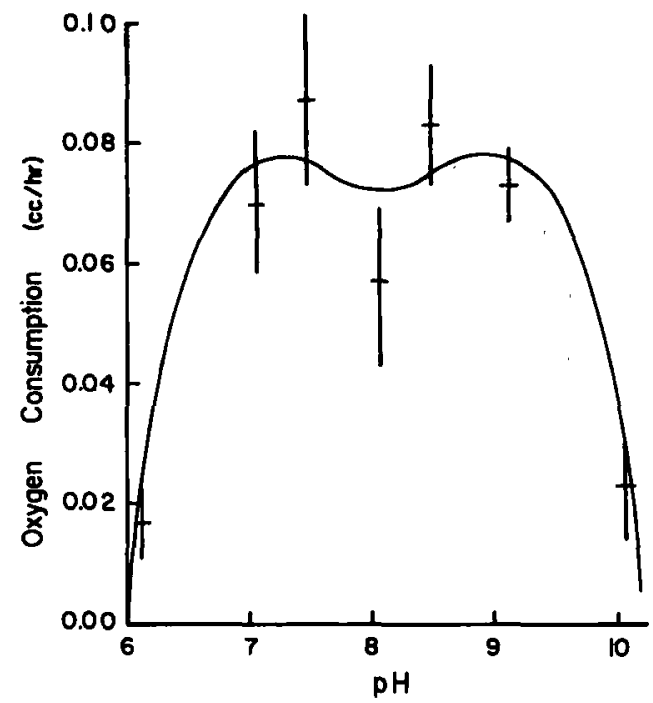

Fig. 2. Relationship of oxygen consumption to $\mathrm{pH}$ in $V$. contectoides.

cally more favourable. The species is capable of existing at the two peak $\mathrm{pH}$ values $(7 \cdot 1$ and 8.9$)$, but it is energetically stressful for them to do so. The graph with its two peaks and intervening trough gives evidence that there are two sets of pre-existing enzyme systems with different $\mathrm{pH}$ optima. This suggests further studies involving snails acclimated to different $\mathrm{pH}$ values to test if there is a corresponding shift in the $\mathrm{pH}$ optima.

The apparent existence of two enzyme systems allows $V$. contectoides to exist in widely fluctuating water pHs. The range for snails in this study varied from $6 \cdot 1$. where approximately half of the snails were dying, to $10 \cdot 1$, where there was an extremely low level of oxygen consumption. Jewell (1929) studied a bog lake in which several species of freshwater snails were found living at $\mathrm{pH}$ values ranging from $6 \cdot 1$ to $7 \cdot 2$. We found no studies with a range of $\mathrm{pH}$ tolerance that compared to our study.

Hochachka \& Somero (1973) describe the probable existence of three time-courses of response for metabolic compensation. They are evolutionary rate compensation, seasonal rate compensation, and immediate rate compensation. The oxygen consumption to $\mathrm{pH}$ relationship in $V$. contectoides appears to be the first published example of immediate rate compensation.

Acknowledgments-We wish to thank Dr. Eugene $\mathrm{H}$. Studier and Dr. Richard W. Dapson for their time and supervision of this study. We also thank Drs. Studier, Dapson and Gary L. Pace for their critical evaluation of our study.

\section{REFERENCES}

AKERLAND G. (1969) Oxygen consumption of the ampullariid snail Marisa cornuarietis $L$. in relation to body weight and temperature. Oikos 20, 529-533. 
BARnes H. \& BARnes M. (1969) Seasonal changes in acutely determined oxygen consumption and effect of temperature for three common cirripedes, Balants balanoides (L.) B. balanus (L.) and Chtamalus stellatus (Poli). J. exp. mar. Biol. 4. 36-50.

BARTHOLOMEW G. A. (1972) Body temperature and energy metabolism. In Animal Physiology: Principles and Adaptions. (Edited by Gordon M. S.), Macmillan, New York.

Berg K.. Lumbye J. \& Ockelmann K. W. (1957) Seasonal and experimental variations of the oxygen consumption of the limpet Ancylus fiuviatilis (O. F. Muller). $J$. exp. Biol. 35. 43-73.

BERG K. \& OCKelmanN K. W. (1959) The respiration of fresh water snails. J. exp. Biol. 36. 690-708.

Daniels J. M. \& ARmitaGE K. B. (1968) Temperature acclimation and oxygen consumption in Physa hawnii Lea (Gastropoda: Pulmonata). Hydrobiologia 33, 1-13.

DAvies P. S. (1966) Physiological ecology of Patella-I. The effect of body size and temperature on metabolic rate. J. mar. hiol. Ass. U.K. 46. 647-658.

FiTCH D. D. (1975) Oxygen consumption in the prosobranch snail Viviparus contectoides (Mollusca: Gastropoda)-I. Effects of weight and activity. Comp. Biochem. Physiol. 51A, 815-820.

HaEser P. E. (1970) O consumo de ongenio em Strophocheilus oblongus musculus (Becquaert. 1948)- Gastropolde pulmonado terrestre. Pesquisas Number 23, 123.

HoAR W. S. \& Hickman C. P.. JR. (1967) A Lahoratory Comparison for General and Comparative Physiology. pp. 286-289. Prentice-Hall, Englewood Cliffs, NJ.

HochachKa P. W. \& SOMERo G. N. (1973) Strategies of Biochemical Adaptation W. B. Saunders, Philadelphia.

HUEBNER J. D. (1973) The effect of body size and temperature on the respiration of Polinices duplicatus. Comp. Biochem. Physiol. 44A. 1185-1197.

JEWELL M. E. (1929) The fauna of an acid stream. Ecology 10. 22-28.
JeWell M. E. \& Brown H. W. (1922) Studies on northern Michigan bog lakes. Ecology 10. 427-475.

LEWIS J. B. (1971) Comparative respiration of some tropical intertidal gastropods. J. exp. Biol. 6. 101-108.

MAson C. F. (1971) Respiration rates and population metabolism of woodland snails. Oceologia 7. 80-94.

NEWELL R. C. (1966) Effect of temperature on the metabolism of poikilotherms. Nature, Lond. 212. 426-428.

Newell R. C. (1969) Effect of fluctuation in temperature on the metabolism of intertidal invertebrates. Am. Zoologist 9, 293-307.

NEWELL R. C. (1973) Factors affecting the respiration of intertidal invertebrates. Am. Zoologist 13, 513-528.

Newell R. C. \& BAYNE B. L. (1973) A review on temperature and metabolic acclimation in intertidal marine invertcbrates. Neth. J. Sea Res. 7. 4I1-420.

NeWT:LL R. C. \& PYE V. I. (1971) Quantitative aspects of the relationship between metabolism and temperature in the winkle Littorina littorea (L.) Comp. Biochem. Physiol. 38B. 635-650.

NFWELl R. C. \& RoY A. (1973) A statistical model relating the oxygen consumption of a mollusk (Littorina littorea) to activity. body size, and environmental conditions. Physiol. Zool. 46. 253-275.

Pye V. I. \& NEwell R. C. (1973) Factors affecting thermal compensation in the oxidative metabolism of the winkle Littorina littorea. Neth. J. Sea Res. 7. 411-420.

Rising T. L. \& ARMITAGE K. B. (1969) Acclimation to temperature by the terrestrial gastropods. Limax maximus and Phylomycus carolinianus: oxygen consumption and temperature preference. Comp. Biochem. Physiol. 30. 1091-11!4.

RoFf J. C. (1973) Oxygen consumption of Limnocalanus macrurus Sars (Calanoida. Copepoda) in relation to environmental conditions. Can. J. Zool. 51. 877-885.

Studier E. H., Dapson R. W. \& Bigelow R. E. (1975) Analysis of polynomial functions for determining maximum or minimum conditions in biological systems. Comp. Biochem. Physiol., 52A. 19-20. 